\title{
The Importance Of Foreign Direct Investments On Economic Development In Transitional Countries: A Case Study Of Kosovo
}

\author{
Halil Kukaj, PhD \\ Economic Faculty, Prizren University, Kosovo \\ Faruk B. Ahmeti, PhD \\ Business School, Roehampton University, London, UK
}

doi: 10.19044/esj.2016.v12n7p288 URL:http://dx.doi.org/10.19044/esj.2016.v12n7p288

\begin{abstract}
The role of investment, in particularly foreign direct investment (FDI), is regarded as one of the most important contributors of economic growth. The past quarter century has witnessed remarkable growth in FDIs flow all over the world. This is due to the fact that many countries, especially developing countries, see FDI as an important element in their overall strategy for economic development. This paper provides a review of the economic impact of FDI, with specific focus on developing countries particularly Kosovo and ex-Yugoslavian countries in the Balkan Peninsula. FDIs contribute to the economic development of host country in two main ways. They include the augmentation of domestic capital and the enhancement of efficiency through the transfer of new technology, marketing and managerial skills, innovation, and best practices. Secondly, FDI has both benefits and costs, and its impact is determined by the country's specific conditions in general and the policy environment in particular. This is in terms of the ability to diversify, the level of absorption capacity, targeting of FDI, and the various opportunities for linkages between FDI and domestic investment. The paper aims to clarify the main causes of failure of foreign direct investments in Kosovo and reviles the importance of indicators that majorly has an institutional nature. Neither the amount nor the effects of foreign direct investment were satisfactory. Therefore, the paper reviles that in this aspect, a wide range of actions needs to be made, which is specifically related to government institutions and the business community.
\end{abstract}

Keywords: Foreign direct investments, economic growth, developing countries 


\section{Introduction}

Due to the economic changes and developments around the globe, many countries lack investments that may lead to new incentives for local and regional development. In most of the transition countries, the transition process from communism and central planning, to open economy, has gone through structural and dramatic changes. Domestic capital, in most of these transition countries, including Kosovo and all former socialist countries in the region, was incapable of meeting the huge investment needs that transition required. In the early stages of the transition process from planned to the market economy, the importance of Foreign Direct Investments (FDI) is seen as crucial and a top priority for policy makers. Thus, many incentives were undertaken in order to facilitate the flow of FDIs in the local market. In the role of FDI in stimulating economic growth, when it comes to transition and undeveloped economies, there is more agreement on the positive effects of FDI in economic development. In this context, Foreign Direct Investments (FDI) presents an important source of new financial sources that will support local economies, especially those in developing countries. Subsequently, not every country is able to attract the right mode of FDI, nor does every investor risk his investments without studying the local conditions in the host country. To understand the interaction between foreign investors and the local conditions in the host economy, it is necessary to understand the motivations of foreign investors. The simplest place to begin is by asking the following questions: What are they doing in the region? Why are they doing it, and what are the factors that influence what they are doing? Comparing FDI with local business conditions (the supply) in host country impact analysis of any of such investments without understanding foreign investor's needs (the demand), would not make much economic sense. Denisia (2010) stated that in order to understand foreign direct investment, one "must first understand the basic motivations that cause a firm to invest abroad rather than export or outsource production to national firms" (p.53).

There are different views presented in literature by different authors regarding on "how" and "to what extent" FDIs affect economic growth in developing countries. FDIs have a direct effect on local and regional economic growth. This is because they contribute to capital accumulation and enable knowhow and technology transfer to the host country. Due to the economic changes and developments around the globe, many countries lack investments that might lead to new incentives for local and regional development. Therefore, the transition process from communism and central planning, to open economy, in most of the countries within this context and also in Kosovo, has made FDIs and their financial potential to be a desirable and appropriate opportunity for creating new financial sources. This is 
accomplished by creating new incentives in an attractive investment environment for FDIs (Weigel, 1997, p. 20).

Additionally, beside a direct impact of FDIs in economic growth, FDIs enhances economic growth indirectly. Here, the direct transfer of technology augments the stock of knowledge in the recipient's country through labor training and skill acquisition, new management practices, and organizational arrangements (De Mello, 1999).

Notionally, though, in the perspective of either neo-classical or endogenous growth models, the effects of FDI on the economic growth of the receiving country varies in the latest development models from their conventional counterparts. Subsequently, the conventional economic growth theories are being augmented by discussing growth in the context of an open economy rather than a closed economy, and the emergence of externalitybased growth models. Even with the inclusion of FDI in the model of economic growth and the perception that FDIs are seen as long-term economic growth, there are other traditional growth theories that restrain the potential impact of FDIs. In addition, there are also traditional growth theories that ling the affect with the short-run level of income, rather than the long-term economic growth. Nevertheless, recent study has increasingly revealed an endogenous long-run impact of FDIs in economic growth determination. According to the neo-classical models, FDI can only affect growth in the short run because of diminishing returns of capital in the long run (Anderson et al., 2014, p.13).

\section{Methodology Implemented in the Study}

The natural surroundings of the analytical studies characterize an important condition that will determine the most suitable and implementable assessment methodology. When studying social sciences and other related fields linked to overall social and economic development, exploration tends to be challenging. As noted by Torraco (2004), studding the development of the most valuable and most complicated assets of any firm (the human resources) needs specific methodologies and approach. Difficulties have a tendency to ascend while taking into account multiple outcomes. Efficiency of FDIs and investment studies, which are linked to inhabitants and local culture of the receiving countries, as well as the cultural development of the investing entity, provides relevant evidence on the degree of success or failure of economic development programs. However, this takes into account several or multiple objectives that may be important when evaluating the overall impact of a particular investment in the overall economic development.

One of the most important elements of the nature of the analytic task is the time that must be spent to carry out the research, and foremost when 
analyzing the impact on overall economic development. In order to answer the research questions, researchers have implemented the combination of two methodologies (quantitative and qualitative) in order to overcome various challenges that the study may bring. As the implementation of two different methodologies is more complicated and more challenging, researchers have conducted the entire research in two phases, each of which had its own methodological approach (Bamberger, 2000, p. 3). Accordingly, researchers provided their personal sets of experience that enables them to analyze the data; however, the implementation of various approaches was aimed at creating an informative and many-faceted description of the research object studied (Bamberger, 2000; Taylor, 2005; Watzlawik \& Born, 2007; Teddlie \& Tashakkori, 2009; Ahmeti, 2013).

To gather the primary data, a structured questionnaire was developed and combined with a semi-structured interview with selected companies. Consequently, this was done with employees at all level within those companies. Hence, the facts used for the analysis involved two different sorts of data. On one side, there are data gathered from institutions showing the overall FDI impact on the economic development of and from previous data that illustrate the development carried out in various countries through FDI activities. The main goal of the implementation and the integrating of the two forms of data (research methodologies and approaches, respectively), is to capture, describe, and understand both aspects of the skilled expertise (Shermon, 2004; Armstrong, 2006; Price, 2011). The structured questionnaire delivered numerical data that are used for descriptive analyses, while the interviews enabled the researcher to gather data for interpretative analysis of the subject studied.

As a means to implement the above mentioned approach, this paper studies some empirical properties of qualitative and quantitative fields of study. However, this serves as a means to benefit and better comprehend how developing countries (specifically Kosovo) see FDIs from an economic perspective. It also shows how these processes and practices are implemented in the field. Even if they are many, the methodological research aspect tends to be focused on macro-level. It tends to describe the dimensions of the world becoming global in a quantitative view. However, there are many issues which cannot be measured in numbers (Lynn, 2003a). As noted by Bosma et al. (2004), tending to measure in macro-level, there are many key aspects that can be ignored and that are crucial for the results of the study (Bosma et al., 2004).

\section{Foreign Direct Investment (FDI)}

There are many definitions of Foreign Direct Investment (FDI), but the most accepted definition is that of the World Trade Organization (WTO). 
According to the WTO, foreign direct investment is considered as any investment where the investor from a country invests in a foreign country in the creation of the asset (property) of the enterprise, with the right to control its business.

In general, FDI is the course of action whereby residents or companies of one country-source country (sometimes referred as 'home country') acquire ownership of assets for the purpose of controlling the production, distribution, and other activities of a company in another country i.e. host country (sometimes referred 'foreign country'). Economically, FDI is a mechanism to transfer resources, including financial capital as well as technology and human resources across national borders while keeping it under the control of the parent company. The FDI definition takes on different meanings depending on whether it is seen from the perspective of the foreign investor or the host country. However, according to Moosa (2002), "there is something in common in both perspectives: a) there is a control through substantial equity shareholding; and b) there is a shift of part of the company's assets, production, or sales to the host country” (p.2).

Current FDI trends have not changed much about the mature definition of FDI. For example, a recent book by Theodore Moran (2012) declares the same opinion that FDI takes place "when a corporation in one country establishes a business operation in another country, through setting up a new wholly-owned affiliate, or acquiring a local company, or forming a joint venture in the host economy (p.3).

The main criteria in considering an investment as a foreign direct investment are the right of participation of foreign entities in control of the enterprise and the ownership of the invested funds. Thus, the right of participation in the control of the enterprise is the main characteristic that distinguishes Foreign Portfolio Investments (FPI) from Foreign Direct Investment (FDI).

According to the International Monetary Fund (IMF), which considers an investment as FDI, it is necessary that the value of the investment should be at least $10 \%$ of the total value of the enterprise assets, or minimum of $10 \%$ of the ordinary shares (Hill, 2007, p. 176).

The participation of at least $10 \%$ is considered to be sufficient to provide the foreign investor participation in the control of the enterprise. However, most authors consider that at least 25\% of foreign investment is seen as minimum in order to provide foreign investors realistic ND effective participation in organizational control of the company. Therefore, the main characteristics of foreign direct investments are:

- $\quad$ The foreign investor has the right to control the organization, and - $\quad$ The foreign investor has the right to profit or participate in the profit made by the organization, based on the investment level. 
Subsequently, the main differences between FPI and FDI are:

- $\quad$ In foreign indirect (portfolio) investment, the investor does not have the right to control (therefore considered as investment rentier), while in foreign direct investment, the investor has the right to control the company and to participate in the decision making process. Thus, this is due to the active role of investors in the overall activities of the company. These investments are considered as entrepreneurial ventures.

When it comes to foreign indirect investment investor, the investment is made mainly in form of financial capital outside the home country; while in the case of foreign direct investment, the investor invests in production factors (financial capital, technology, labor and know-how) outside the home country.

\section{Types of Foreign Investments}

At different periods of the development of the human society, the attitudes of different countries towards FDI have changed. Until recently, some countries maintained a restrictive stance. While some countries have closed their markets to foreign direct investments, others were liberal and they opened their markets to foreign direct investment. Therefore, they see foreign capital as an opportunity for market development. Lately, most of the countries that have implemented a restrictive stance, seeing the effects of FDIs in the economic development of countries that have open their markets, have changed their attitudes toward FDIs. Hence, they are becoming open to foreign direct investment and are implementing various programs with various measures to attract foreign direct investment. In this context, Kosovo has recognized the importance of foreign capital and the impact that the flow of that capital has for the local economy. In general, foreign investment can be done in different formats and constellation. Thus, they all fall into two general formats, Foreign Portfolio Investment (FPI) and Foreign Direct Investment (FDI).

Foreign direct investment can be sorted according to various criteria. By this form of investment, FDIs can be divided into Joint Venture and Individual Investments.

Joint ventures are the joint investment of external partners with local partners, in the creation of the joint goals and in order to reach their interests. This form of joint investment makes it possible for investors to control their investment together, to lead together, bears the risk together, and share profit made from the invested capital, regardless of the format of the capital (Dasa \& Das, 2012).

Consequently, partners can contribute in different forms and capital structure, such as financial capital, material capital (land, buildings, 
equipment, infrastructure, etc.), technology, "know-how", or combined. Based on several facts, joint ventures can be divided into:

- $\quad$ Bilateral joint investment (partners are from two countries), and

- Joint investments multilateral (partners are from more than two countries).

Furthermore, the participation of the foreign partner in a joint investment might be as follows:

- $\quad$ Minor (Minority Joint Venture), i.e. the participation of the foreign partner in the joint investment is less than $49 \%$,

- $\quad$ Equals (Partnership), i.e. 50: 50\%,

- $\quad$ Majority (Majority Joint Venture), i.e. foreign partner's share of the joint venture is higher than $50 \%$.

The participation of partners in a joint investment determines their participation in the joint venture's control and participation in the profit sharing. The motives of partners for joint investments are numerous and vary from case to case and on whether it is a local or a foreign partner (Chowdhury \& Chowdhury, 2001).

The motives of the local partner are: profit, financing their projects/incentives, application of new technologies, the use of knowledge research, increased export because of the product's quality produced with modern technology, the expansion of their market share, use of a trade name, using distribution channels, etc., which are provided by the foreign partner.

The motives of the foreign partner (non-resident) are: profit, exploitation of cheap labor, exploitation of local raw materials with affordable prices, use of energy and other objects of infrastructure at affordable prices, using established channels by local distribution partner, easier penetration of the local market by using "familiarization" of local partner with the local culture, creating better links with local government through local partner, etc.

The main limitation of joint investment is the possibility of submission of disputes between partners regarding the decisions on production, placement, and profit-sharing. For instance, one partner may require reinvestment of profit, while the other partner may be more interested in transferring his profit abroad.

Individual Investments: Investments are subject to the creation of an entirely individually owned company abroad, home country. An entity has the option to create a fully owned company abroad, parent country, in two ways:

- $\quad$ By acquiring an existing organization within the intended market (country) or

- $\quad$ Investing in the creation of an entirely new company (referred to as "investment in green field"). 
Regardless of the format of the investment, they both have positive and negative sides. However, the purchase of existing company has advantages, which are manifested as it offers advantages for the investor, such as:

- $\quad$ The investor can immediately begin the utilization of existing capacities.

- $\quad$ The investor can immediately secure a market share.

- Through the existing experience and established format of the organization, the investor can overcome any legal issues regarding xenophobia by foreigners.

This form of hesitation of foreign investors has been reviled after the breaking down of centralized and closed economic oriented countries in South Eastern Europe (SEE) and their transition to market economies, specifically within the Balkan Peninsula. All these countries have implemented and are still in the phase of implementing the privatization process of Publically Owned Enterprises (POE). During the privatization process, the majority of existing enterprises in the countries concerned were sold to foreign entities at prices below fair value. For this reason, in recent years, foreign investment in these countries is made mainly through the acquisition of existing enterprises. The main advantages of foreign investment in the creating of new company (Greenfield Investment) relates to the fact that the investor has the opportunity:

- $\quad$ To carry out construction and modern technical standards, and

- $\quad$ To organize business processes as required by modern technology, without any interference from any previously set conditions within any existing organization.

FDIs can also differ in terms of the nature of their investment. This is based on the criterion of whether they invested in the same activities as in their home country or not. The FDIs can be distinguished between:

- $\quad$ Horizontal foreign direct investment, and

- $\quad$ Vertical foreign direct investment - conglomerates.

Horizontal Foreign Direct Investments: These are investments where the investor (or investing company) made investments outside their home country on the same production or service activity, which deals with the place of origin. Thus, through horizontal FDI, the investor invests in the expansion of the same activities outside the home country. A concrete example of horizontal foreign direct investment is Volkswagen (VW) Company, as they invested in the Czech Republic auto industry (Skoda). In addition, VW also invested in the acquisition of Seat Company in Spain.

Vertical Foreign Direct Investments: These are investments where investors (or the investing company) do not invest outside their home country in activities outside the core activity. However, these activities are not related to its core activity or products, nor can it be used as 
complementary or supporting products/services to its primary production of the field in which they are active.

\section{Foreign Portfolio Investment (FPI)}

Foreign Portfolio Investment (FPI) represents investments of foreign entities in the purchase of securities issued by government institutions, e.g. bonds, treasury bills, etc. On the other hand, it refers to the securities issued by corporations, but without the right of the investor in participating in the control of the business subject to securities issuers.

The main features of foreign indirect investment (or portfolio investment) are that the investor does not have the right to control the subject securities issuers. The main motive of investors in investing is the realization of profit by fixed rate, which is paid by the plan to determine that before.

Investment or buyer, securities are usually individuals, corporations, commercial banks, insurance companies, trusts, pension, and investment funds. On the other hand, issuers of securities, usually, are the government, municipalities, and corporations. Through emissions, they borrow the securities of the capital necessary to finance certain works.

\section{Holders of Foreign Direct Investment}

Foreign direct investment bodies are mainly identified as multinational corporations (MNCs) and huge corporations that have the possibility to invest in other foreign countries (regions or markets). Multinational corporations are corporation that is based within their own country, but they have already created a network of affiliates spread across different countries of the world. Here, the parent organization controls and runs on an integrated model by eligibility opportunities which is global. In its network of subsidiaries in different countries of the world, multinational corporations creates through their own investment, that which is considered as foreign direct investment. Through its subsidiaries, multinational corporations carry out business operations, and offers products and services. Often times, they are developed within or through their subsidiaries, and the combination of miscellaneous business operations, which then can easily access different markets in different parts of the globe. Also, subsidiaries of the same corporation, located in different countries of the world, in many cases do trade with each other. This kind of trade is called intra-corporate trade (trade within the system). Thus, this trade enables them to gain advantages within the market (where those subsidiaries are operating). Also, this enables the organization to create a circle that would create opportunities for all its subsidiaries within a specific region or market. The main goals of such a relation and interaction include:

Maximizing overall profit at the corporate level, and 
- $\quad$ Strengthening the market position of certain subsidiary through financial discharge system between members.

Subsequently, the main motives for the implementation of the transfer price strategy are:

Transfer of Profit: The subsidiary in a foreign market realizes high profit and wants to carry it (for various reasons, e.g. fiscal) to main organization or any other subsidiary. Then, in the case of exchange with other members of the system (corporation), the delivery of goods is calculated with lower prices, whereas the supplies are made with higher prices. By doing so, the profit will be withdrawn. At the same process, the profit flows which will later be transferred to another member of the system.

Avoiding the Payment of Customs Duties: In avoiding the payment of custom duties, the subsidiary in the country with a high rate of customs make the transfer of goods to be at lower prices. Thus, this reduces the basis of customs clearance.

Fighting Competition: Through the calculation of the low prices, the subsidiary strengthened competitive position in the foreign market.

Political risk: The subsidiary operating in a country with high political and economic risk, are able to manage and create appropriate led policy of keeping small amount of cash and investments as possible. This is done at a given period of time in a specific country.

There are numerous reasons why investors (individuals or organizations) decide to carry out investments outside the home country. However, they can be systemized into two major groups, namely: 1) Related to market(s), 2) Cost reasons.

Market Oriented Investment: The market oriented investment include creating market scale, avoiding trade barriers, and consumer trends

1. Creating Market Scale: The market rate is established by increasing the number of foreign markets in which the company engages with its subsidiaries. In creating market scale, the company is using the advantages of the economy of scale. Economies of scale mean lower production costs due to the increasing quantity of products or/and services.

2. Avoiding Trade Barriers: Basically, countries may apply different trade barriers for imports, e.g. complete closure of the market, high rates of customs duties, and different restrictions on quantity or value. In those cases, for enterprises to be able to avoid such barriers, they invest in a specific country. This is done to create a subsidiary owned and operated as local enterprise, which are not restricted with any possible trade barriers. Therefore, they are not treated as foreign companies.

3 Customer trends: Due to cultural differences or nationalist tendencies, consumers often prefer to buy local products. For this reason, 
companies make decisions to invest in the country. They offer their products and identify them as local products.

Cost Reduction Oriented: Generally, corporations are interested to constantly reduce the cost of production of their products/services. To be able to achieve lower productions costs, organizations invest their production capacities in a country which is rich in raw materials and which offers cheap labor. Therefore, the most attractive countries, concerning these factors, are developing countries. One of the factors that could push corporations to invest abroad is different benefit from fiscal incentives, material incentives, and non-financial incentives. These incentives provide host governments for attracting FDI, and the issue related to the environment and its protection.

\section{Trends of Foreign Direct Investment in the World}

Ahead of conducting a performance analysis of FDIs, it is necessary to first get acquainted with the meaning of some terms and to distinguish between them. First, one should be aware of the meaning and should be able to distinguish between FDI flows and the stock of FDI. The FDI flow represents the amount of assets invested within a given time period, which is usually one year; while the stock of FDI means the amount of accumulated funds invested for several years. Also, the foreign investment distinguishes between incoming FDI (from outside) and FDI outflows (by country). The incoming FDI investment is when a foreign entity invests in a particular country, while outgoing FDI investments occurs when the domestic firms invest abroad or outside their home country. Next, we will reflect the flow of FDI in the world, in developed countries, and in developing countries.

\begin{tabular}{|c|c|c|c|c|c|c|c|}
\hline Countries & FDI & \multicolumn{7}{|c|}{ Years } \\
& flow & $\mathbf{1 9 7 0}$ & $\mathbf{1 9 8 0}$ & $\mathbf{1 9 9 0}$ & $\mathbf{2 0 0 0}$ & $\mathbf{2 0 1 0}$ & $\mathbf{2 0 1 4}$ \\
\hline World & IN & 13.346 & 54.078 & 207.455 & 1.400 .541 & 1.309 .001 & 1.228 .262 \\
& OUT & 14.151 & 51.590 & 241.498 & 1.226 .633 & 1.451 .365 & 1.354 .046 \\
\hline Developed & IN & 9.491 & 46.576 & 172.526 & 1.137 .996 & 618.586 & 498.761 \\
Countries & OUT & 14.100 & 48.397 & 229.584 & 1.088 .321 & 989.576 & 822.826 \\
\hline Developing & IN & 3.854 & 7.479 & 34.834 & 216.865 & 684.399 & 729.501 \\
Countries & OUT & 51 & 3.192 & 11.914 & 135.116 & 400.144 & 531.220 \\
\hline
\end{tabular}

Table 1. The flow of Foreign Direct Investment, in USD mil. (Source: UNCTAD-World Investment Report, 2015)

The year 2000, shows a decrease. This is explained by the global financial crisis. Also, it shows that by year 2000, developed countries dominate in both, incoming FDIs and in FDI outflows. After this year, this share varies in favor of developing countries. Therefore, this phenomenon is a result of the transition process that is based on the opening of markets within those closed in transition countries. What was the stock of FDI in the 
world, in developed countries, and in developing countries by 2014, is shown in the following Table 2.

\begin{tabular}{|c|c|c|c|c|c|c|c|}
\hline \multirow[t]{2}{*}{ Countries } & \multirow{2}{*}{$\begin{array}{l}\text { FDI flow } \\
\text { directions }\end{array}$} & \multicolumn{6}{|c|}{ Years } \\
\hline & & 1970 & 1980 & 1990 & 2000 & 2010 & 2014 \\
\hline \multirow{2}{*}{ World } & $I N$ & - & 598.951 & 2.081 .147 & 7.450 .022 & 19.906.662 & 26.038 .824 \\
\hline & OUT & - & $54 \mathrm{C}$ & & & & \\
\hline \multirow{2}{*}{$\begin{array}{l}\text { Developed } \\
\text { Countries }\end{array}$} & $I N$ & - & & & 5.6 & & \\
\hline & OUT & - & 477.203 & 1.946 & 7.07 & 17.1 & \\
\hline Develo & IN & - & 297.319 & 517.200 & 1.735 .488 & 6.256 .066 & 9.035 .022 \\
\hline Countries & OUT & - & 72.101 & 146.094 & 857.107 & 3.313 .808 & 5.319 .937 \\
\hline
\end{tabular}

Table 2. FDI Stock (in USD mil.) (Source: UNCTAD, World Investment Report, 2015)

As revealed in table 2, the stock of FDI worldwide has significantly increased. If compared, between year 1980 and 2010, it is noticeable that the stock of inward FDI has increased by 2.75\%, while the stock of FDI outflows to 3.69\%. Also, it shows that, after the year 1990, the contribution of FDI to the development of developing countries is enormous. In order to get a more specific insights related to the individual countries that have contributed to the overall impact of FDIs globally, we have analyzed the IN and OUT movement of foreign investments in some countries. Thus, this can be seen in Table 3 below:

\begin{tabular}{|c|c|c|c|c|c|c|c|c|}
\hline \multirow[b]{2}{*}{ No. } & \multirow[b]{2}{*}{ Country } & \multicolumn{7}{|c|}{ Years } \\
\hline & & $\begin{array}{l}\text { FDI flow } \\
\text { directions }\end{array}$ & 1970 & 1980 & 1990 & 2000 & 2010 & 2014 \\
\hline \multirow{2}{*}{1} & \multirow{2}{*}{ USA } & $I N$ & 1.26 & 16,918 & 48,422 & 314,007 & 198,049 & 92,397 \\
\hline & & OUT & 7.59 & 19.23 & 30,982 & 142,626 & 277,779 & 336,943 \\
\hline \multirow{2}{*}{2} & \multirow{2}{*}{ China } & $I N$ & - & 57 & 3,487 & $40,714.80$ & 114,734 & 128.5 \\
\hline & & OUT & - & - & 830 & 915.8 & 68,811 & 116 \\
\hline \multirow{2}{*}{3} & \multirow{2}{*}{ Holland } & $I N$ & & & $11,063.30$ & 63,855 & 7,184 & $30,253.30$ \\
\hline & & OUT & & & $14,371.90$ & $75,634.40$ & 68,358 & $40,808.70$ \\
\hline \multirow[t]{2}{*}{4} & \multirow{2}{*}{$\begin{array}{l}\text { Hong } \\
\text { Kong }\end{array}$} & $I N$ & 50 & 710 & 3,275 & $54,581.90$ & $70,540.70$ & $103,254.20$ \\
\hline & & OUT & 0 & 82 & 2,448 & $54,078.80$ & $86,247.20$ & $142,700.50$ \\
\hline \multirow[t]{2}{*}{5} & \multirow{2}{*}{ UK } & $I N$ & 1,488 & 10,123 & $30,461.10$ & $121,897.70$ & $58,954.30$ & 72,241 \\
\hline & & OUT & 1,678 & 7,881 & $17,948.20$ & $235,398.20$ & $46,633.20$ & $59,628.50$ \\
\hline \multirow{2}{*}{6} & \multirow{2}{*}{ Singapore } & $I N$ & 93 & 1,236 & $5,574.70$ & $15,515.30$ & $55,075.80$ & 67,523 \\
\hline & & OUT & 0 & 98 & $2,033.80$ & $6,650.30$ & $33,377.40$ & $40,659.90$ \\
\hline \multirow{2}{*}{7} & \multirow{2}{*}{ Germany } & $I N$ & - & - & $2,962.40$ & $198,276.50$ & $65,642.40$ & $1,830.90$ \\
\hline & & OUT & - & - & $24,234.80$ & 56,557 & $125,450.80$ & 112,227 \\
\hline \multirow{2}{*}{8} & \multirow{2}{*}{ Spain } & $I N$ & 222 & 1,493 & $10,797.20$ & $39,575.10$ & $39,872.50$ & $22,904.10$ \\
\hline & & OUT & 43 & 311 & $2,685.30$ & $58,213.30$ & $37,843.80$ & $30,688.20$ \\
\hline \multirow{2}{*}{9} & \multirow{2}{*}{ France } & $I N$ & 621 & 3,328 & $16,506.20$ & 27,495 & $13,889.20$ & $15,191.10$ \\
\hline & & OUT & 365 & 3,137 & $38,302.20$ & $161,947.70$ & $48,156.10$ & $42,869.10$ \\
\hline \multirow{2}{*}{10} & \multirow{2}{*}{ Canada } & IN & 1,823 & 5,807 & $7,582.30$ & $66,795.10$ & $28,400.40$ & 53,864 \\
\hline & & OUT & 931 & 4,098 & $5,236.50$ & $44,678.20$ & $34,722.80$ & 52.62 \\
\hline
\end{tabular}

Table 3. FDI flow by countries in USD mil. (Source: UNCTAD, World Investment Report, 2015) 
Table 3 reveals which countries lead in terms of FDI. Therefore, the data regarding incoming FDI can be revealed. These data provides information that represents the most appropriate and suitable countries to invest in.

Ranking of countries by FDI inflows and the stock value of FDI participation in the overall countries GDP in 2014, is revealed in the Table 4 below:

\begin{tabular}{c|c|c|c|c|c|}
\multicolumn{3}{|c}{$\begin{array}{c}\text { Ranking of countries according to the } \\
\text { inflow of FDI }\end{array}$} & \multicolumn{3}{c|}{$\begin{array}{c}\text { Ranking of countries according to the } \\
\text { participation of FDI inflows in GDP }\end{array}$} \\
\hline No. & Country & FDI Stock & No. & Country & $\%$ \\
\hline 1 & USA & $5,409.884$ & 1 & Hong Kong & 535.1 \\
\hline 2 & UK & $1,662,857.8$ & 2 & Singapore & 296.2 \\
\hline 3 & Hong Kong & $1,549,848.8$ & 3 & Holland & 76.7 \\
\hline 4 & China & $1,085,293$ & 4 & UK & 56.5 \\
\hline 5 & Singapore & $912,355.4$ & 5 & Spain & 51.3 \\
\hline 6 & Germany & $743,511.5$ & 6 & Canada & 35.3 \\
\hline 7 & France & $729,147.2$ & 7 & USA & 31.1 \\
\hline 8 & Spain & $721,879.4$ & 8 & France & 25.6 \\
\hline 9 & Holland & $664,441.9$ & 9 & Germany & -- \\
\hline 10 & Canada & $631,315.6$ & 10 & China & 10.5 \\
\hline
\end{tabular}

Table 4. Ranking of countries according to the participation of FDI inflows in GDP shown in USD mil. (Source: UNCTAD, World Investment Report, 2015)

The data in the Table 4 reveals that USA is the first place for the stock of inward FDI, followed by UK, and so on. However, for the participation of the stock of FDI inflows in the country's GDP, it is obvious that the most successful country in attracting FDIs was Hong Kong, followed by Singapore, and so on.

The above countries which are most successful in attracting FDIs worldwide are mainly developed countries. Another issue occurs when it comes to developing countries. Table 5 below shows the flow of FDI inflows in the countries of the Free Trade Area of Central Europe (CEFTA).

\begin{tabular}{|c|c|c|c|c|c|c|c|}
\hline \multirow{2}{*}{ No } & Countries & \multicolumn{7}{|c|}{ Years } \\
& & 2009 & 2010 & 2011 & 2012 & 2013 & 2014 \\
\hline 1 & Kosova & 348 & 446 & 465 & 277 & 339 & 183 \\
\hline 2 & Albania & 996 & 1.051 & 876 & 855 & 1.266 & 1.093 \\
\hline 3 & B \& H & 250 & 406 & 496 & 351 & 283 & 562 \\
\hline 4 & Montenegro & 1,527 & 760 & 558 & 620 & 447 & 497 \\
\hline 5 & Serbia & 2,896 & 1,686 & 4,932 & 1,299 & 2,053 & 1,996 \\
\hline 6 & Macedonia & 201 & 213 & 479 & 143 & 335 & 348 \\
\hline 7 & Moldavia & 208 & 208 & 288 & 195 & 236 & 207 \\
\hline
\end{tabular}

Table 5. Incoming FDI flows in the CEFTA countries in USD mil. (Source: UNCTAD, World Investment Report, 2015 and CBAK, Annual report 2014, p. 150) 
The data of this table shows that 2012 was the year where all countries had declining incoming FDI. In 2014, the largest absorber of FDI was Serbia, Albania was second, and was followed by Kosovo.

Whereas, the stock of FDI inflows and the share of FDI inflows in GDP in CEFTA countries can be seen from the data in the following table 6:

\begin{tabular}{|c|c|c|c|c|c|c|c|}
\hline \multirow{2}{*}{ No. } & \multirow{2}{*}{ Countries } & \multicolumn{4}{|c|}{ Years } & \multirow{2}{*}{$G D P$} & \multirow{2}{*}{$\begin{array}{l}\text { Participation of } \\
\text { inflow FDI } \\
\text { stock in GDP in } \\
\text { year } 2014\end{array}$} \\
\hline & & 1990 & 2000 & 2010 & 2014 & & \\
\hline 1 & Kosovo & - & - & 2,385 & 3,582 & 7.2 & $49.70 \%$ \\
\hline 2 & Albania & - & 247 & 3,255 & 4,466 & 13,223 & $33.80 \%$ \\
\hline 3 & B \& H & - & 1,083 & 6,651 & 7,383 & 18,044 & $40.90 \%$ \\
\hline 4 & Montenegro & - & - & 4,231 & 4,983 & 4,506 & 110.6 \\
\hline 5 & Serbia & - & - & 24,919 & 29,564 & 50,861 & $58.10 \%$ \\
\hline 6 & Macedonia & - & 540 & 4,439 & 5,14 & 11,325 & $45.40 \%$ \\
\hline 7 & Moldavia & - & 449 & 2,964 & 3,647 & 7,928 & $46.00 \%$ \\
\hline
\end{tabular}

Table 6. The stock of FDI inflows in the CEFTA countries in USD mil. (Source: UNCTAD, World Investment Report, 2015 and CBAK, Annual report 2014, p. 150)

As can be seen from the above table (Table 6) on the share of the stock of FDI inflows in GDP in 2014, Montenegro first holds the first place, followed by Serbia, and finally Kosovo which took the third place, with a share of $49.7 \%$.

\section{FDIs in Kosovo}

As Kosovo is one of the poorest countries in Europe, the inflow of FDI plays a crucial role on overall Kosovo's economic development. The following Table 7, shows the inflow of FDI through the years:

\begin{tabular}{|c|c|c|c|c|c|c|c|c|}
\hline \multirow[b]{2}{*}{ No } & & \multicolumn{7}{|c|}{ Year } \\
\hline & & 2009 & 2010 & 2011 & 2012 & 2013 & 2014 & $\begin{array}{c}2015 \\
\text { Jan - Jun }\end{array}$ \\
\hline 1. & $\begin{array}{l}\text { Value in } \\
\text { USD mil. }\end{array}$ & 287.4 & 368.5 & 384.4 & 229.1 & 280.2 & 151.3 & 163.7 \\
\hline
\end{tabular}

Table 7. Incoming FDI flows in Kosovo in Euro mil. (source: CBAK, Annual report 2016)

The data of this table shows that FDI had significant shaking, with a significant decline in 2012. On the other hand, the lowest level is reached in year 2014, while the first half of 2015 shows a remarkable increase.

There are many different countries that contributed their investment to Kosovo's economy in the form of direct investment. The following Table 8 shows the country of origin of FDIs that have regarded Kosovo as an appropriate country to invest in. 


\begin{tabular}{|c|c|c|c|c|c|c|c|c|c|c|}
\hline \multirow{2}{*}{ Year } & \multirow{2}{*}{ FDI } & \multicolumn{9}{|c|}{ Countries } \\
\hline 2009 & 287.4 & 75.2 & 14.5 & 22.7 & 6.2 & 50.8 & 23.3 & 15.5 & 11.8 & 67.2 \\
\hline 2010 & 368.5 & 91.5 & 4.9 & 35.1 & 38.9 & 34.0 & 20.3 & 21.1 & 12.6 & 110.1 \\
\hline 2011 & 384.4 & 66.6 & 34.7 & 30.9 & 80.1 & 16.2 & 11.2 & 19.6 & 14.3 & 110.8 \\
\hline 2012 & 229.1 & 49.5 & 65.6 & 43.8 & 14.3 & 9.3 & 4.7 & 0.4 & 10.8 & 30.7 \\
\hline 2013 & 280.2 & 21.7 & 88.6 & 41.7 & 10.7 & 7.0 & 19.3 & 10.7 & 12.7 & 67.8 \\
\hline 2014 & 151.3 & 29.4 & 20.2 & 38.2 & -39.5 & -9.4 & 20.4 & 30.1 & 14.6 & 47.6 \\
\hline$\sum$ & $1,700.9$ & 333.9 & 228.5 & 212.4 & 110.7 & 107.9 & 99.2 & 97.4 & 76.8 & 434.2 \\
\hline
\end{tabular}

Table 8. FDI inflows in Kosovo by origin countries in USD mil.

As illustrated in Table 8, the FDI in Kosovo originates mainly from industrialist and developed countries; whereas, the most important source of FDI investments originates from Germany. Thus, this was followed by investments from Turkey, Switzerland, and so on.

The following Table 9, shows where was the focus of the flow of foreign direct investment in Kosovo. Thus, this was separated by economic activities in the period of $2009-2015$.

\begin{tabular}{|c|c|c|c|c|c|c|c|c|}
\hline No & Industry & \multicolumn{7}{|c|}{ Year } \\
\hline & Total & $\mathbf{2 8 7 . 4}$ & $\mathbf{3 6 8 . 5}$ & $\mathbf{3 8 4 . 4}$ & $\mathbf{2 2 9 . 1}$ & $\mathbf{2 8 0 . 2}$ & $\mathbf{1 5 1 . 3}$ & $\mathbf{1 6 3 . 7}$ \\
\hline 1 & Agro & 13.1 & 0.9 & 0.6 & 0.3 & 0.4 & 0.2 & 0.3 \\
\hline 2 & Mining & 7 & 17.7 & -5.2 & -25 & -14.1 & 4.2 & -7.7 \\
\hline 3 & Industrial & 57.6 & 101.1 & 46.9 & 27.4 & 11.5 & -34 & 5.9 \\
\hline 4 & Energy & 8.7 & - & 0.2 & 2.2 & 48.8 & 13.4 & 7.1 \\
\hline 5 & Construction & 35.5 & 54.2 & 133.1 & 31.1 & 17.3 & -19.9 & 29.4 \\
\hline 6 & Trading & 16.2 & 6.8 & 11.6 & 9.3 & 14.6 & 8.4 & 5.1 \\
\hline 7 & Gastronomy & 2.4 & - & 0.2 & 0.5 & 0.8 & 0.4 & - \\
\hline 8 & Transport and & 21.9 & -15.9 & 29 & 32.4 & 51 & -9.1 & -3.5 \\
\hline 9 & communication & & & & & & & \\
\hline 10 & Financial services & 75.3 & 39.4 & 33 & 22.4 & 4.4 & 41.9 & 25.3 \\
\hline 11 & Immobile & 43.9 & 75.5 & 60.5 & 115.7 & 136.1 & 142.2 & 97.3 \\
\hline
\end{tabular}

Table 9. Kosovo FDI flows by economic activity in EURO mil.

As shown in the Table 9, the most dominate investment is in real estate sector, followed by investments in financial services. Investments in the industry (or other industrial activities) are small and their tendency leans toward further decrease after year 2010. This situation can be explained by the fact that the majority of foreign direct investment in industry are made through the privatization process. Consequently, majority of enterprises have been sold at prices below their real value, while the share of investments for the creation of new enterprises ("greenfield investment") were small. Another feature of these investments was that the majority of foreign 
investments were in form of conglomerates. Here, investors had no plan and experience in business development, but their motive for investing was the low purchase price of the companies in the privatization process.

Another characteristic of FDIs in Kosovo is that the level of reinvesting the earnings and profit, from previously privatized organizations, was very low. Also, funds collected from the sale of companies in the privatization process, have not been activated and directed toward the financing of the economic development of Kosovo. Rather, the fund has been held abroad for several years. In year 2014, the amount of funds deposited in the account in the name of "Kosovo Privatization Agency" reached around $€ 559$ mil. Thus, this amount could have an enormous impact on the overall economic development of Kosovo, if returned and invested properly.

\section{Conclusion}

In conclusion, developing countries have been able to increase the inflow of FDI in recent times. This was due to the fact that the intensification has not led to a consistent positive effect of foreign direct investments on local economic development. Furthermore, this was specifically in those countries that were not able to create and implement an appropriate strategy to attract the foreign investors. The results of the various studies reviewed, provide four main implications in terms of diversification, enhancing the absorptive capacity of local firms, providing opportunities for linkages between domestic and foreign investors, and showing a targeted approach to foreign direct investment.

One of most important indicator that was revealed and that has shown to be crucial for attracting investors, is the ability of government to promote policies that enhance the domestic capacity of its inhabitants. They advocated that government must aim at attracting particular categories of FDI that are capable of generating spillover effects in the overall economy. Therefore, the emphasis must be focused more on employing promotional resources to attract a subset of FDIs flows, rather than FDI in general. Thus, this is because they are not equally interested to contribute to local economic development.

Consequently, we conclude by reiterating the fact that regardless of the benefits that countries have from FDIs, it is essential that the growth process in a particular economy, in specific in developing countries, must start from within, rather than from outside. There are many indicators that have shown that a strong investment in human capital accumulation and a significant increase in infrastructure provision, are the most important indicator that can be seen to attract foreign investors. Upcoming studies should focus more on empirical studies and elaborate elements that are seen 
as crucial for attracting FDIs, which can be developed from within the country. Hence, more focus is on country specific studies, rather than on the cross country studies. This is because none of the countries are similar, even if they are in the same region and/or have same historical background. More importantly, the category of FDI should be targeted to be attracted and to conduct a sectorial analysis to determine which sectors or industries that are more attractive to FDIs, and then to promote them.

\section{References:}

Ahmeti (2013). Building Community Capacity for Tourism Development in Transitional Countries: Case of Kosovo. European Journal of Scientific Research, Volume 115 (No 4), pp. 536-543.

Alan A. Bevan \& Saul Estrin (2000). The Determinants of Foreign Direct Investment in Transition Economies, William Davidson Institute Working Papers Series

Anderson et al. (2014). Promoting Trade Competitiveness in Developing Countries. UK: Cambridge Scholars Publishing

Armstrong (2006). STRATEGIC HUMAN RESOURCE MANAGEMENT: A GUIDE TO ACTION (3rd Edition ed.). London : Kogan Page.

Bamberger (2000). Integrating Quantitative and Qualitative Research in Development Projects. Washington: World Bank Publications.

Blomstrom \& Kokko (2001). Foreign Direct Investment and Spillovers of Technology, Int. J. Technology Management, No 5-6

Bosma et al. (2004). The value of human and social capital investments for the business performance of startups. Small Business Economics, 23(3): 227236.

Chowdhury \& Chowdhury (2001), “A theory of joint venture life cycle”, International Journal of Industrial Organization, 19, 319-343.

Dasa \& Das (2012). Foreign direct investment, joint ventures and export. Journal of Business Management and Economics, Vol. 3(5). pp. 179-189, DeMello (1999). Foreign direct investment-led growth: Evidence from time series and panel data. Oxford Economic Papers, 51(1), 133-151.

Denisia (2010). Foreign direct investment theories: an overview of the main FDI theories. European Journal of Interdisciplinary Studies, 53-59.

Hill (2007). International Business: Competing in the Global Marketplace. NY: Cengage Learning. NY: McGraw-Hill/Irwin

Hill (2003). International Business, Competing in the Global Marketplace, Irwwin Mc Grow- Hill.

Ilia Kristo (2004). Biznesi Ndërkombëtar, PEGI, Tiranë.

Ilia Kristo (2007). Biznesi Ndërkombëtar, Pegy, Tiranë

Kalil Kukaj (2014). Biznesi Ndërkombëtar, Kolegji FAMA, Prishtinë. 
Lynn (2003a). PEDAKSI: methodology for collecting data about survey nonrespondents.

Moosa (2002). Foreign direct investment. Theory, evidence and practice. Hampshire - UK: Palgrave Publisher, Ltd. (formerly Macmillan Press, Ltd). Moosa (2002). Foreign Direct Investment - Theory, Evidence and Practice, New York.

Moran (2012). Foreign direct investment. London: John Wiley \& Sons Price (2011). Human Resource Management. Hampshire: Cengage Learning EMEA. Quality \& Quantity, 37, pp. 239-61

Shermon (2004). Competency Based HRM: A Strategic Resource for Competency Mapping, Assessment and Development Centres. Banglore: Tata McGraw-Hill Education.

Taylor (2005). Integrating Quantitative and Qualitative Methods in Research. Maryland: University Press of America.

Teddlie \& Tashakkori (2009). Foundations of Mixed Methods Research: Integrating Quantitative and Qualitative Approaches in the Social and Behavioral Sciences. SAGE Publications.

Torraco (2004). Challenges and choices for theoretical research in human resource development. Human Resource Development Quarterly, Vol. 15(2), pp.171-188.

Watzlawik \& Born (2007). Capturing Identity: Quantitative and Qualitative Methods. Maryland, USA: University Press of America.

Weigel (1997). Foreign Direct Investment. World Bank Publications. Washington, USA. 